\title{
C-terminal part of alpha-synuclein mediates its activity in promoting proliferation of dopaminergic cells
}

\author{
Juanjuan Yin ${ }^{1 \dagger}$, Tao Wang ${ }^{1 \dagger}$, Junyan Han ${ }^{1}$, Chen Zhang ${ }^{1}$, Qiulan Ma ${ }^{1}$, Xin Li ${ }^{1}$, Furong Cheng ${ }^{1}$, Guangwei Liu', \\ Yaohua Li', Kenji Uéda ${ }^{1,3^{*}}$, Piu Chan', Shun Yu ${ }^{1,2^{*}}$
}

From 2011 International Conference on Molecular Neurodegeneration

Shanghai, China. 22-24 September 2011

\section{Background}

Although abnormal aggregation of alpha-synuclein $(\alpha-$ syn) is involved in several neurodegenerative diseases, its biological functions remain poorly understood, which limits our understanding of its pathogenic mechanisms. $\alpha$-Syn has been shown to exhibit a MAP-like activity and promote the assembly of microtubules. Since microtubules play a pivotal role in proliferative cell division, it is possible that $\alpha$-syn affects cell proliferation by facilitating microtubule assembly. The role of $\alpha$-syn in promoting cell proliferation was reported previously in PC12 dopaminergic cells overexpressing $\alpha$-syn. Here, we extended this study aiming at finding the association between the cell proliferation effect of $\alpha$-syn and its microtubule assembly activity, and identifying the potential active domain for the effect $\alpha$-syn on cell proliferation.

\section{Method}

By exploiting the property that the 11-mer repeats of synuclein molecules are able to mediate a rapid intracellular translocation of these proteins across the plasma membrane without being degraded by the cellular proteolytic system, we added recombinant full-length $\alpha$-syn (wild type and A53T and A30P mutants) and $\beta$-syn to the culture medium of MES23.5 dopaminergic cells, and observed their intracellular translocation, subcellular distribution and effects on cell proliferation.

† Contributed equally

'Department of Neurobiology and Sino-Japan Joint Laboratory for Neurodegenerative Diseases, Beijing Institute of Geriatrics, Xuanwu Hospital of China Capital Medical University, Beijing 100053, China

Full list of author information is available at the end of the article

\section{Result}

We found that all the synuclein molecules could enter the cells where they were localized in both the cytoplasm and nucleus. However, only the wild-type $\alpha$-syn, which had been shown to have microtubule assembly activity, was able to promote proliferation of the MES23.5 cells. The A53T and A30P mutant $\alpha$-syn as well as $\beta$-syn, which had been proved not to possess microtubule assembly activity, did not exhibit any effect on cell proliferation. Since the $\alpha$-syn activity in microtubule assembly was shown to be related to its specific functional domain, we then generated different functional fragments (N-terminal 1-65aa, NAC 66-95aa and C-terminal 96-140aa) and tested their activities in cell proliferation. We showed that all the $\alpha$-syn fragments could enter the cells, but with different subcellular localizations. The $\mathrm{N}$-terminal and NAC fragments were localized in the cytoplasm and the C-terminal fragment mainly in the nucleus. In accordance with the activity for the C-terminal part of $\alpha$-syn in microtubule assembly, only the NAC and C-terminal fragments exhibited the activity in cell proliferation. The $\mathrm{N}$-terminal fragment without microtubule assembly activity did not promote cell proliferation.

\section{Conclusion}

The above results suggest that the $\alpha$-syn function in promoting cell proliferation is associated with its microtubule assembly activity with the functional domain localized in its C-terminal part.

\footnotetext{
Author details

'Department of Neurobiology and Sino-Japan Joint Laboratory for Neurodegenerative Diseases, Beijing Institute of Geriatrics, Xuanwu Hospital
} 

Hypoxia Medicine, Xuanwu Hospital of China Capital Medical University, Beijing 100053, China. ${ }^{3}$ Division of Psychobiology, Tokyo Institute of Psychiatry, Tokyo 156-8585, Japan.

Published: 7 February 2012

doi:10.1186/1750-1326-7-S1-S21

Cite this article as: Yin et al:: C-terminal part of alpha-synuclein

mediates its activity in promoting proliferation of dopaminergic cells.

Molecular Neurodegeneration 2012 7(Suppl 1):S21.

Submit your next manuscript to BioMed Central and take full advantage of:

- Convenient online submission

- Thorough peer review

- No space constraints or color figure charges

- Immediate publication on acceptance

- Inclusion in PubMed, CAS, Scopus and Google Scholar

- Research which is freely available for redistribution

Submit your manuscript at www.biomedcentral.com/submit 